\title{
Entrepreneurial Initiatives as a Microfoundation of Dynamic Capabilities
}

\author{
Christian A. Mahringer \& Birgit Renzl \\ University of Stuttgart \\ Chair of Management and Organization \\ Keplerstr. 17 \\ 70174 Stuttgart, Germany \\ Contact: Christian.mahringer@bwi.uni-stuttgart.de \\ "Author Accepted Manuscript"
}

To cite this paper:

Mahringer, C.A., Renzl, B. (2018). Entrepreneurial initiatives as a microfoundation of dynamic capabilities. Journal of Accounting and Organizational Change, 14, 1, 61-79.

https://doi.org/10.1108/JAOC-11-2016-0066 


\title{
Entrepreneurial Initiatives as a Microfoundation of Dynamic Capabilities
}

\begin{abstract}
Purpose - The purpose of this paper is to show how entrepreneurial initiatives in organizations serve as a microfoundation of dynamic capabilities and, thus, foster change in organizations.

Design/methodology/approach - This paper revises and applies conceptual as well as empirical research on dynamic capabilities, their microfoundations and corporate entrepreneurship. In addition, it develops a model of how entrepreneurial initiatives, operative routines and capabilities interact.

Findings - The paper develops a model of how entrepreneurial initiatives in organizations represent a microfoundation of dynamic capabilities. First, the model shows that environmental dynamism reduces fit of operative routines and capabilities. Second, the model states that entrepreneurial initiatives are triggered by operative routines and capabilities in respect of environmental dynamism. Third, the model suggests that entrepreneurial initiatives disrupt operative routines and capabilities and, thus, restore their fit in dynamic environments. The paper contributes to current research on dynamic capabilities, their microfoundations and corporate entrepreneurship.

Originality/value - This paper addresses the tension between routinization and the entrepreneurial nature of dynamic capabilities. Considering entrepreneurial initiatives as a microfoundation shows that dynamic capabilities might be entrepreneurial, but still preserve their patterned nature enabling repeated execution. This approach provides a way to reconcile the two sub-streams in dynamic capability research and preserve their ontological assumptions. Moreover, this paper extends the literature on dynamic capabilities by ascertaining how individual and group level entrepreneurial initiatives operate within a broader context.
\end{abstract}

Keywords: Dynamic capabilities, organizational routines, multi-level, microfoundations, entrepreneurial initiatives, intrapreneurship, corporate entrepreneurship.

Paper Type: Conceptual paper 


\section{Introduction}

During the last several decades, dynamic capabilities have received widespread attention in management research. Environmental dynamism influences the fit of current operative routines and capabilities in organizations. The latter require dynamic capabilities to deal with this issue (Teece et al., 1997). Thus, dynamic capabilities enable organizations to adapt operative routines and capabilities to dynamic environments, which is a key concern in contemporary organizations (Zollo and Winter, 2002; Winter, 2003).

However, the nature of dynamic capabilities remains ambiguous. Some scholars regard dynamic capabilities as sets of organizational routines (e.g. Eisenhardt and Martin, 2000; Zollo and Winter, 2002). However, because routines are phenomena that develop within specific trajectories (Vergne and Durand, 2011) the question remains how do they enable "dynamic" adaptation and change. In this regard, Teece (2012) argues that entrepreneurial behavior of managers in organizations might also be components of dynamic capabilities. Creative acts and entrepreneurial intent are necessary for evaluating and stipulating organizational change. Concisely, the dynamic capability concept simultaneously includes seemingly opposing aspects of routinization and entrepreneurship.

This tension raises two major questions. First, it is currently unclear how this tension between the supposedly divergent perspectives of a routine-based approach and (corporate) entrepreneurship might be resolved. Such conceptual clarity is important in order to advance research on dynamic capabilities. Second, corporate entrepreneurship involves individuals and groups and, thus, might not solely be considered an organization level phenomenon (Kuratko et al., 2005). This hints at a movement that endorses consideration of the micro level of dynamic capabilities in order to gain a deeper understanding of the phenomenon (Felin et al., 2015; Winter, 2013; Salvato and Rerup, 2011).

The purpose of this article is to reveal how entrepreneurial initiatives represent a microfoundation of dynamic capabilities. Specifically, this article builds on research on dynamic capabilities and the microfoundations movement that has emerged within this literature. Moreover, we borrow insights from research on corporate entrepreneurship in order to explain entrepreneurial initiatives as a microfoundation of dynamic capabilities. The paper develops a model that demonstrates how entrepreneurial initiatives in organizations disrupt operative routines and 
capabilities to cope with the dynamic environment and, hereby, constitute a microfoundation of dynamic capabilities.

The paper is organized as follows. First, it reviews research on dynamic capabilities, their microfoundations and corporate entrepreneurship. Second, the paper develops a model to illustrate how entrepreneurial initiatives represent a microfoundation of dynamic capabilities. Third, it discusses implications for research and practice and shows directions for future research as well as limitations.

This paper contributes to research and practice in several ways. First, it contributes to research on dynamic capabilities by highlighting the specific role of entrepreneurial initiatives and how they interact with operative routines. Second, this paper contributes to microfoundations research by emphasizing the role of entrepreneurial individuals and groups in the attainment of organizational level phenomena such as dynamic capabilities. Third, it contributes to research on corporate entrepreneurship by embedding entrepreneurial initiatives in a broader strategic context. Considering practical implications, the paper argues in favor of nurturing entrepreneurial initiatives as a microfoundation of dynamic capabilities and, thus, fostering organizational change.

\section{Review}

\subsection{Dynamic capabilities}

Teece et al. (1997) and Teece and Pisano (1994) introduced the concept of dynamic capabilities in the debate on management research. These authors argue that organizations increasingly face dynamic environments that are characterized by rapid change. Consequently, they question how organizations might sustainably capture value in such environments and achieve competitive advantage. According to the authors, dynamic capabilities enable firms to achieve new forms of competitive advantage. Since then, several scholars refined this understanding of dynamic capabilities (e.g. Barreto, 2010; Helfat et al., 2007; Eisenhardt and Martin, 2000; Zollo and Winter, 2002; Winter, 2003; Ambrosini et al., 2009).

The tremendous attention given to dynamic capabilities in management research has several reasons. First, dealing with environmental dynamism is of utmost importance for organizational strategy and behavior. Bourgeois and Eisenhardt (1988), for instance, argue that organizations in highly dynamic environments struggle with defining appropriate strategies since environmental changes occur quickly and are hard to predict. Therefore, specific capabilities are required to deal 
with those changes (McCarthy et al., 2010). Second, dynamic capabilities imply that organizations focus on and modify their operative routines and capabilities (Zollo and Winter, 2002). Teece et al. (1997) argue that the relevance of dynamic capability research also resides in normative implications that differ from market-based perspectives and extend resource-based perspectives. More specifically, the dynamic capability view emphasizes organizational capabilities and routines, but still considers how these relate to the external environment.

This renewed perspective on how organizations cope with dynamic environments has triggered research that strives to unravel how dynamic capabilities operate, i.e., what they do (Winter, 2003; Peng et al., 2008; Helfat and Winter, 2011; Zahra et al., 2006; Zollo and Winter, 2002; Barreto, 2010; Teece, 2007; Di Stefano et al., 2014). In their initial contribution, Teece et al. (1997) hint at this question by emphasizing the fundamental role of operative capabilities and routines in organizations. However, the authors do not explain the specific link between operative and dynamic capabilities. Zollo and Winter (2002, p. 340) define dynamic capabilities as "a learned and stable pattern of collective activity through which the organization systematically generates and modifies its operating routines in pursuit of improved effectiveness". This definition shows that dynamic capabilities might operate in two different ways (Di Stefano et al., 2014). First, they might modify operative routines and capabilities (Aragón-Correa and Sharma, 2003; Zahra et al., 2006). Second, dynamic capabilities might also generate new operative routines and capabilities. However, Di Stefano et al. (2014, p. 315) argue that this distinction is not problematic as dynamic capabilities might be able to accomplish both (Santos and Eisenhardt, 2005; Benner and Tushman, 2003). In a nutshell, following the definition of Zollo and Winter (2002), dynamic capabilities operate by generating or modifying organizational routines and capabilities (Eriksson, 2014, p. 73). They, thus, maintain and restore fit with the requirements that arise from dynamic environments.

Understanding how dynamic capabilities operate also requires knowledge about their nature, i.e., what they are. Eisenhardt and Martin (2000) state that dynamic capabilities are routines that enable organizations to create new resource configurations. Moreover, Winter (2003) explicitly contrasts dynamic capabilities with ad-hoc problem solving and notes that the latter is not routine in nature and, thus, not constituent of dynamic capabilities. Zollo and Winter (2002, p. 340) also hint at this idea when they define dynamic capabilities as "patterns of collective activity". Furthermore, scholars have argued that regarding dynamic capabilities as sets of organizational 
routines enables measurability through observability (i.e., routines might be observed in practice) (Di Stefano et al., 2014, p. 313; Helfat et al., 2007, p. 37). Consequently, dynamic capabilities might be understood as sets of organizational routines (Amit and Zott, 2001; Aragón-Correa and Sharma, 2003).

The notion of dynamic capabilities as organizational routines does have important implications for the nature of dynamic capabilities. The concept of organizational routines and the role of routines in organizations have been discussed extensively in the literature (Nelson and Winter, 1982; Collis, 1994; Dosi et al., 2008; Cohen et al., 1996; Winter, 2003; Gilbert, 2005; Dosi et al., 2000; Cyert and March, 1963; Stene, 1940). Cohen et al. (1996, p. 683) define an organizational routine as "executable capability for repeated performance in some context that has been learned by an organization in response to selective pressures". First, this definition emphasizes the role of context-dependent learning (Parmigiani and Howard-Grenville, 2011, p. 417), which implies that routines develop within specific trajectories because efficiency is gained by building on familiar knowledge (Sydow et al., 2009). If we define dynamic capabilities as organizational routines they themselves might develop within specific trajectories (Vergne and Durand, 2011; Gilbert, 2005). Second, the definition states that routines are repetitive phenomena. Repetitiveness is vital since it explicitly excludes one-time events such as ad-hoc problem solving and instead emphasizes repeated performances (Winter, 2003). Third, the definition states that routines react to selective pressures. This property is also important since it links routines to external aspects such as environmental dynamism. In conclusion, regarding dynamic capabilities as sets of organizational routines enables a more comprehensive understanding in terms of context and organizational learning. However, the question remains how dynamic capabilities enable organizations to adapt to dynamic environments if they are considered to be phenomena that develop in specific trajectories.

By contrast, other scholars have argued that dynamic capabilities are linked to the notion of entrepreneurship (Engelen et al., 2014; Helfat et al., 2007; Wales et al., 2013; Zahra et al., 2006; Teece, 2012, 2014, 2007, 2016). Zahra et al. (2006) propose that entrepreneurial activities affect the selection of resources and promote learning. Resources and learning processes seed operative capabilities and organizational knowledge that are linked to dynamic capabilities. On one hand, dynamic capabilities build on organizational routines, whereas on the other, they are generative in nature (Helfat and Peteraf, 2009, p. 95; Eisenhardt and Martin, 2000). However, the specific link 
between corporate entrepreneurship and dynamic capabilities remains rather vague. "While entrepreneurs and managers are the key agents of change, dynamic capabilities may also be embedded in organizational routines and may be employed to reconfigure the firm's resource base by shedding idle or decaying resources" (Zahra et al., 2006, p. 922). Teece (2012) explicitly contrasts routines with entrepreneurial actions of individuals. Moreover, he argues that both aspects might be constitutive of dynamic capabilities. "Dynamic capabilities are not just the gears and drivetrain of the organizational machine; they include the entrepreneurial consciousness, imagination, and human action that guide it. The human action involves sensing, creating and cocreating, seizing, and transforming" (Teece, 2014, p. 339). Teece (2016, p. 214) also hints at the relevance of entrepreneurial managers for dynamic capabilities, but also asserts that research on this issue is still in its beginnings.

In summary, the concept of dynamic capabilities emphasizes fit between the external environment and operative capabilities and routines. Moreover, scholars have explored how dynamic capabilities induce change and found that they modify and generate operative routines and capabilities. However, understanding of the nature of dynamic capabilities seems to be ambivalent (Wohlgemuth and Wenzel, 2015; Schreyögg and Kliesch-Eberl, 2007). On one hand, they are considered as routines that enable repeated execution; alternatively, the notion of routines implies that they develop within specific trajectories underemphasizing their entrepreneurial potential. We argue that in order to resolve this tension between routines and entrepreneurship it is vital to unravel the microfoundations of dynamic capabilities.

\subsection{Microfoundations of dynamic capabilities}

In the last few years scholars have called for unravelling the microfoundations of dynamic capabilities (Abell et al., 2008; Barney and Felin, 2013; Felin and Foss, 2005; Felin et al., 2012; Felin and Foss, 2009; Felin et al., 2015; Salvato and Rerup, 2011). Felin et al. (2012) state that microfoundations are mechanisms that explain abstract phenomena such as dynamic capabilities on a lower analytical level. "The microfoundations aspect has to do with the treatment of individual actors in the context of organizational routines and capabilities, especially issues of motivation and agency" (Winter, 2013, p. 121). A contribution that provides a coherent understanding of dynamic capabilities as a microfoundations issue is provided by Salvato and Rerup (2011). The authors distinguish between the organizational, the group and the individual level. Further, they argue that 
dynamic capabilities operate on organizational routines by aligning them with dynamic environments. They also argue that individual behaviors underpin routines on the individual level. However, the authors point out that the link between individual behaviors, routines and dynamic capabilities still needs further exploration. Consequently, we address this research gap.

Microfoundations research is particularly concerned with individuals' contributions to dynamic capabilities. Several scholars have recognized the role of managers in creating and maintaining capabilities (Adner and Helfat, 2003; Helfat and Martin, 2015; Salvato and Rerup, 2011; Salvato, 2009). Unraveling managerial microfoundations, including aspects such as cognition (e.g. Gavetti, 2005; Eisenhardt et al., 2010; Helfat and Peteraf, 2015), human capital (e.g. King and Tucci, 2002; Rothaermel and Hess, 2007) and social relationships (e.g. Acquaah, 2007; Kemper et al., 2013) seems to be relevant.

There are reasons why microfoundations research is beneficial for understanding the nature of dynamic capabilities. Abell et al. (2008), for example, argue that collectivist explanations are common in management science and further argue that causal explanations typically require elaboration of the micro level to create a coherent understanding of the phenomenon. Felin et al. (2015, p. 589) explain that considering microfoundations enables scholars to understand the constituents (e.g., individuals, routines, structures) that underpin organizational phenomena. According to the authors, explanatory black boxes, therefore, are prevented.

In summary, scholars have called for unravelling the microfoundations of dynamic capabilities. As management research typically neglects the role of microfoundations, consideration of lower level entities that constitute dynamic capabilities might create additional insights (Wilden et al., 2016). More specifically, we argue that entrepreneurial initiatives are a microfoundation of dynamic capabilities that constitutes their generative character. In the following, we review research on corporate entrepreneurship that enables us to provide a coherent understanding of entrepreneurial initiatives as a microfoundation of dynamic capabilities.

\subsection{Corporate entrepreneurship}

The term corporate entrepreneurship has received widespread attention (Kuratko et al., 2015). One reason for this interest might be that corporate entrepreneurship is believed to augment exploration (Ireland and Webb, 2007) and firm performance (Lumpkin and Dess, 1996; Rauch et al., 2009). Furthermore, the interest of scholars in corporate entrepreneurship seems to rely on the notion that 
it is a way to overcome inertia and create market-firm-fit (Ahuja and Lampert, 2001; Lant and Mezias, 1990). Ahuja and Lampert (2001), for example, find that organizations tend to favor familiarity, maturity and propinquity, which prevents the attainment of breakthrough innovation and that corporate entrepreneurship provides a way to overcome those traps.

Corporate entrepreneurship is "the process whereby an individual or a group of individuals, in association with an existing organization, create a new organization or instigate renewal or innovation within that organization" (Sharma and Chrisman, 1999, p. 18). Corporate entrepreneurship, typically, has been regarded as a firm level phenomenon (Covin and Slevin, 1991; Covin and Miles, 1999; Ireland et al., 2003). However, the definition provided above shows that individuals also play a major role in the attainment of corporate entrepreneurship. Thus, corporate entrepreneurship is not solely an organization level phenomenon, but is also attained by individuals and groups in the organizational context. In the following, we refer to those iterations of the corporate entrepreneurship process as entrepreneurial initiatives. Those initiatives in new products, services and/or businesses arise from internal opportunity recognition (Shane and Venkataraman, 2000; Newey and Zahra, 2009, p. 83). The notion of entrepreneurial initiatives refers to entrepreneurial activities within firms (Kuratko and Audretsch, 2013; Kuratko et al., 2005).

Several sub-streams of research on corporate entrepreneurship have highlighted the relevance of individuals. First, some scholars have specifically focused on individuals' characteristics in corporate entrepreneurship (Hisrich, 1990; Naffziger et al., 1994; Pinchot III, 1985; De Jong et al., 2015; Ireland et al., 2009; Ates et al., 2015; Hostager et al., 1998; Haynie et al., 2010). Naffziger et al. (1994), for instance, argues that personal characteristics and goals as well as the personal and business environment of the corporate entrepreneur might affect decisions to behave entrepreneurially. The authors embed this conceptualization in the larger organizational context. Moreover, Ireland et al. (2009) argue that individuals' beliefs, attitudes and values are antecedents of a corporate entrepreneurship strategy. Second, researchers elaborated the role of diverse employee groups such as middle managers in corporate entrepreneurship (Kuratko et al., 2005; Ren and Guo, 2011; Dutton et al., 1997; Wooldridge et al., 2008; Fulop, 1991; Lassen et al., 2009; Boyett and Currie, 2004; Hornsby et al., 2002). Wooldridge et al. (2008), for example, finds that middle managers play a central role in corporate entrepreneurship. More specifically, Kuratko et al. (2005) argue that middle managers perceive organizational antecedents (i.e., the context) and, 
hence, seize entrepreneurial opportunities and orchestrate relevant resources. Moreover, entrepreneurial behavior of middle managers results in organization level outcomes such as product market diversification, enhancement of innovation capabilities and strategic drifts as well as individual level outcomes. "We believe this area of research (the role of individuals in corporate entrepreneurship, added by the authors) will continue to expand due to the critical importance of behavioral changes that are involved with entrepreneurial activity inside organizations" (Kuratko et al., 2015, p. 248).

To conclude, considering research on corporate entrepreneurship might enable scholars to understand the entrepreneurial microfoundations of dynamic capabilities. Whereas dynamic capability research largely remains on the organizational level, corporate entrepreneurship research shows that understanding this phenomenon requires us to unravel the role of individuals that drive entrepreneurial initiatives (i.e., their microfoundations).

\section{Model: Entrepreneurial initiatives as a microfoundation of dynamic capabilities}

The purpose of this article is to explain how entrepreneurial initiatives represent a microfoundation of dynamic capabilities. We develop a model of how entrepreneurial initiatives represent a microfoundation of dynamic capabilities (Figure 1). In defining the levels involved, we rely on the conceptualization of Salvato and Rerup (2011) and consider the organizational, the group and the individual level. The following chapters explain step-by-step the specific links and mechanisms of how entrepreneurial initiatives represent a microfoundation of dynamic capabilities.

Insert figure 1 here

\subsection{Operative capabilities consist of bundles of organizational routines}

Following prior research, we assume that an organization is built of operative capabilities that consist of bundles of routines (Pavlou and El Sawy, 2011; Winter, 2003). This argument is, for instance, supported by Dosi et al. (2008, p. 1167) and Dosi et al. (2000, p. 4) who argue that routines might be regarded as building blocks of capabilities. A more illustrative example is 
provided by Peng et al. (2008). The authors analyze data from 189 manufacturing plants in six countries and identify 'improvement' and 'innovation' as critical capabilities that influence operational performance. Moreover, the authors explain that those capabilities consist of bundles of diverse routines such as process management (improvement-capability) or cross-functional product development (innovation-capability). Another empirical example is provided by Dutta $e t$ al. (2003) who find that the pricing capability in a Midwestern manufacturing firm consists of bundles of routines such as data gathering, documenting prices and recalling information from those documents. Therefore, as shown in Figure 1, we exemplarily display an operative capability that is underpinned by a bundle of routines (i.e., illustrated by several layers). Moreover, as routines are collective phenomena they reside on the group level, but still expand to the individual level as individuals perform those routines (Feldman and Pentland, 2003).

\subsection{Environmental dynamism reduces fit of operative routines}

Research has extensively discussed how operative routines relate to dynamic environments (Henderson and Clark, 1990; Zollo and Winter, 2002; Schreyögg and Kliesch-Eberl, 2007, p. 916). The understanding of this link is deeply connected to the notion of inertia. Routines provide guidance for organizational behavior, but might also develop within specific trajectories. Several streams of literatures emphasize this argument (Sydow et al., 2009, p. 696 ff.; Schreyögg and Kliesch-Eberl, 2007, p. 916 ff.). Researchers of path dependency, for instance, argue that feedback effects of trial-and-error decisions result in dynamically self-reinforcing processes. Those processes eventually lead to fixed decision patterns and lock-ins (Sydow et al., 2009; Arthur, 1989; Vergne and Durand, 2011). This point of view is also shared by Zahra et al. (2006, p. 928) when they propose that operative routines are difficult to change when they have been used repeatedly in a similar manner. In a contemporary case study, Wenzel (2015) shows that the funeral industry in Berlin (Germany) stabilized its strategic premises and action patterns (i.e., routines) even though the market changed radically. This environmental change was due to discount funeral homes entering the market and the rise of the internet that leveraged marketing capabilities of those discount funeral homes. Consequently, revenues dropped and the funeral industry "buried itself'. The decline in revenues reflected the reduced fit between internal routines and the external context in which the organization operates (Helfat et al., 2007, p. 7) 
Given the assumption that routines develop within specific trajectories, fit of those routines is reduced when profound changes in the external environment occur (Vergne and Durand, 2011, p. 374). The reason that firms develop routines is because specific actions are amplified by positive feedback effects (Levitt and March, 1988, p. 320). However, in dynamic environments demand might vary, competitors may offer more attractive products, governments and the industry might initiate regulations and technology and product requirements might change (Bourgeois and Eisenhardt, 1988; McCarthy et al., 2010). Consequently, current routines are no longer adequate and have to be changed (Gilbert, 2005). However, radical change that is not aligned with routines might be inhibited, i.e., environmental change causes variation in the valuation of opportunities that a company might pursue. In addition to that, firms can only pursue some of those opportunities. If environmental dynamism diminishes the value of pursuable opportunities, fit decreases (Helfat et al., 2007).

Empirical findings show that environmental dynamism does indeed reduce fit of operative routines (Collinson and Wilson, 2006; Glasmeier, 1991; Haveman, 1992; Jansen et al., 2006; Nadkarni and Narayanan, 2007; Argote, 1982). In an analysis of saving and loan associations in California, for example, Haveman (1992) shows that organizations that adapt to rapid and substantial changes in the external environment have a higher propensity to realize short-term financial returns and long-term survival. Moreover, Collinson and Wilson (2006) analyzed two Japanese organizations and showed that inert routines did result in major problems when environmental turbulence occurred.

In conclusion, operative routines are considered phenomena that develop within specific trajectories. Even though these routines have proved beneficial in a specific environment, environmental dynamism might reduce fit of operative routines and the capabilities they constitute.

\subsection{Entrepreneurial initiatives are triggered and informed by operative routines in relation to environmental dynamism}

Previously we argued that environmental dynamism might reduce fit of operative routines and capabilities. Therefore, we propose that entrepreneurial initiatives might be a suitable means to meet and anticipate the changes in the environment. Subsequently, they might modify those operative routines or create new ones. 
As indicated in Figure 1, we propose that entrepreneurial initiatives are informed and triggered by the response of operative routines to environmental dynamism. Actors in organizations perceive operative routines because they are often involved in those routines (Feldman and Pentland, 2003). Moreover, those actors might perceive dynamism in the external environment (Teece, 2007). Matching internal routines with the external environment might lead to the perception that operative routines do not fit anymore. This perception might trigger an entrepreneurial initiative that strives to change the operative routines in order to realign them with the requirements from the external environment.

A production manager, for instance, knows the specific production routine because her work is part of this routine (e.g., she knows which tasks have to be accomplished and which products to be made). This manager, in observing the external environment, may notice that competitors offer customized products and that customers prefer those customized products. Consequently, she might consider whether the present production routine could be realigned to enable similar customization or whether it is necessary to adapt the routine, for instance, by applying a new production framework that is more flexible and faster. Additionally, she might think about cultural and political contingencies linked to the production routine that might ease or exacerbate the implementation of a new production framework.

Research on corporate entrepreneurship does support those arguments. First, it has been shown that entrepreneurial initiatives are informed and triggered by environmental dynamism (Miller, 1983; Zahra, 1993). Stopford and Baden-Fuller (1994), for instance, argue that opportunities and threats that emerge from dynamic environments trigger corporate entrepreneurship. Hornsby et al. (2009, p. 238) explain that entrepreneurial initiatives are "pursued in light of environmental opportunities and threats, with the purpose of creating a more effective alignment between the company and conditions in its external environment." Similarly, Ireland et al. (2009, p. 30) propose that environmental dynamism is positively related to the propensity of individuals to pursue corporate entrepreneurship.

Second, corporate entrepreneurship research has shown that entrepreneurial initiatives also depend on internal context characteristics. Those characteristics might also emerge within organizational routines. Kuratko et al. (2005), for instance, explain that the perception of organizational antecedents such as managerial support, work discretion, reward, time availability and boundaries shape entrepreneurial behavior of middle managers. This view relates to a larger 
movement that elaborates environments that are conducive to entrepreneurial initiatives (Kuratko et al., 1990; Hornsby et al., 2002; Hornsby et al., 2013; Kuratko et al., 2014; De Jong et al., 2015; Alpkan et al., 2010). Burgelman (1983a) takes a strategic perspective and highlights how the structural context leads to adjustment of behavior in operational units to create balance with corporate strategy. Ren and Guo (2011) explain that the attention structure of firms affects whether middle managers perceive opportunities and consequently trigger entrepreneurial initiatives. Courpasson et al. (2014) shows how a manager's entrepreneurial initiative depends on interaction with other individuals as well as shared norms and rules. Briefly, research on corporate entrepreneurship has shown that internal contextual aspects (that might emerge from and within organizational routines) inform and trigger entrepreneurial initiatives.

Moreover, Figure 1 shows that entrepreneurial initiatives are both individual and group level (i.e., collective) phenomena. Therefore, we conceptualize them both on the individual and the group level. Wales et al. (2011) hints at this idea when he argues that corporate entrepreneurship is not homogeneously dispersed across the firm, but might reside in specific units or even specific individuals. In analyzing entrepreneurial initiatives in ten firms, Stopford and Baden-Fuller (1994) find that those initiatives develop in several steps. First, individuals and small teams work on new ideas that are mainly independent of the larger organization. Second, those initiatives spread across the organization and result in strategic renewal. Third, those initiatives are embedded in the wider organizational context. As shown in this study, we regard entrepreneurial initiatives as starting from individual action and then spreading across the organization affecting the group level (Burgelman, 1983b). Figure 1 indicates this point of view with a spiral that starts from the individual level and then moves to the group level.

In summary, we have shown that entrepreneurial initiatives in organizations are a vital microfoundation that disrupts organizational routines and restores their fit with dynamic environments. Individuals perceive fit between operative routines and capabilities and match them with the external environment. If those routines no longer fit, these individuals may initiate entrepreneurial initiatives that eventually reach the group level.

\subsection{Entrepreneurial initiatives disrupt operative routines}

Finally, we explore how entrepreneurial initiatives affect routines. We call the mechanism by which entrepreneurial initiatives affect operative routines "disruption" (see also Antoncic and 
Hisrich, 2003) - disruption quickly modifies operative routines or generates new routines. Thus, disruption enables the adaptation of routines to the changing requirements of the environment. Antoncic and Hisrich (2003, p. 13), for instance, highlight how entrepreneurial behavior applies disruptive changes to routines since it represents a departure from the norm. Disruption implies that schemata and accepted repertoires of behavioral patterns that are incorporated in routines are challenged. The organization might be unwilling to accept those changes, most likely resulting in resistance to change. There are two ways for entrepreneurial individuals and groups to execute this mechanism successfully. First, they might try to convince top management of the need for change by selling issues and building coalitions (Dutton et al., 2001; Ren and Guo, 2011). Second, they might siphon off resources and develop ideas covertly. In such a case, by the time the entrepreneurial initiatives is discovered, it is too late to stop it - for instance, because significant investments have been already redirected elsewhere or because a step back would result in major losses (Knight, 1967, p. 493).

There is also rich empirical support for the disruption mechanism of entrepreneurial initiatives (Abetti, 1997; Augsdorfer, 2005; Burgelman, 1983b; Lassen et al., 2009; Courpasson et al., 2014; Ettlie et al., 1984). Abetti (1997), for instance, describes how a team of entrepreneurial actors at the electronics firm Toshiba successfully developed and introduced the first laptop, despite the fact that top management did not support or fund this product development and its distribution. Thus, its development took place "under the table".

Reconsider the example of the production routine introduced above. Assume the production manager decides that it is vital to change the production framework. She might start to talk about this issue with colleagues and those colleagues themselves might talk to others. Some might even ask external experts that are familiar with the new production framework. Additionally, the respective group will create drafts of how the new framework should look and they might start selling their ideas to management in order to get funding and approval (i.e., the initiative becomes a collective phenomenon). Moreover, political and cultural dynamics might arise when different groups with different interests (e.g., maintaining versus changing the original framework) interact. The entrepreneurial initiative modifies the production framework and, thus, disrupts the underlying production routine. Since the new framework enables the flexible production of customized products, as demanded by customers and as offered by competitors, the modified routine exhibits an improved fit with the external environment. 


\section{Discussion}

\subsection{Implications for research}

This paper provides several contributions for research. First, it contributes to research that elaborates on the nature of dynamic capabilities (Schreyögg and Kliesch-Eberl, 2007). Many scholars define dynamic capabilities as high level routines that shape operational routines (Winter, 2003; Eisenhardt and Martin, 2000). However, Teece, (2012, 2014, 2016) argues that routines are not the only components that constitute dynamic capabilities and that entrepreneurial behavior of individuals should also be considered. We develop this insight by outlining the mechanisms by which entrepreneurial initiatives might constitute a microfoundation of dynamic capabilities. We believe that two aspects have to be considered in order to understand this tension between entrepreneurship and routinization. First, applying a microfoundations lens shows that entrepreneurial initiatives might reside on the individual and group level. As indicated in our model, the mechanism of how dynamic capabilities exert their entrepreneurial effect resides on those levels. A microfoundations lens is a suitable way to examine the nature of this tension. This is in line with Teece $(2012,2014,2016)$ who emphasized the role of entrepreneurial managers (i.e., the individual level) for dynamic capabilities. Moreover, we provide an alternative approach to this tension than prior research. Wohlgemuth and Wenzel (2015), for instance, find that higher routinization occurs at strategic levels whereas operational levels are less routinized. Our conceptualization offers an alternative logic to considering this tension between routinization and entrepreneurship by distinguishing between the organizational, the group and the individual level. Second, our approach also underlines that routinization and entrepreneurial initiatives are not mutually exclusive. If organizations succeed in embracing entrepreneurship, entrepreneurial initiatives might become repetitive and, thus, patterned. This idea is also consistent with perspectives that regard dynamic capabilities as semi-structured routines (Eisenhardt and Martin, 2000; Eisenhardt and Sull, 2001). In summary, our model might offer one potential resolution for the tension between entrepreneurship and routinization in dynamic capability research. We hope that it contributes to an improved conceptual clarity within dynamic capability literature.

Second, this paper contributes to microfoundations research. Scholars have called for a more detailed understanding of the roles individuals play as microfoundations of phenomena such as dynamic capabilities (Wilden et al., 2016). Felin and Foss (2005), for instance, state that they are 
frustrated about the neglect of the role of individuals in this literature. Salvato and Rerup (2011) also ask for clarification of the role diverse actors play in shaping higher level entities. We contribute to this research gap by exemplifying entrepreneurial initiatives in organizations as a microfoundation of dynamic capabilities. Past research has particularly focused on cognition as a microfoundation of dynamic capabilities. However, we argue that cognition results in behavior and that behavior might influence organization level phenomena. Thus, behavior is a vital element that should gain more attention in microfoundations research (Salvato and Rerup, 2011). Finally, prior research on the microfoundations of dynamic capabilities has largely focused on top management as "lonely heroes" shaping capabilities (Adner and Helfat, 2003; Helfat and Martin, 2015). By contrast, research on corporate entrepreneurship has also highlighted the role of middle managers that act in an entrepreneurial way and fundamentally change organizations (Kuratko et al., 2005; Kuratko et al., 2015). Thus, by examining entrepreneurial initiatives in organizations, we not only consider top management as influencers of dynamic capabilities, but extend microfoundations research to other managers and employees (Wooldridge et al., 2008; Renzl et $a l ., 2013)$. This extension shifts the role of top management from "lonely heroes" to inspiring leaders that shape the corporate context within which capability-building occurs (Di Stefano et al., 2014).

Third, this paper contributes to research on corporate entrepreneurship. Kuratko et al. (2005), for instance, claims that research should elaborate how middle managers' entrepreneurial behavior influences organizational outcomes. We provide a model of how those entrepreneurial initiatives are embedded in the larger organizational context. Our model also integrates the notion of corporate entrepreneurship in the management literature and shows paths for fertilization between those literatures (Amit and Zott, 2001; Baker and Pollock, 2007; Zahra et al., 2006; Barringer and Bluedorn, 1999).

\subsection{Implications for practice}

This paper also offers several managerial implications. The concept of dynamic capabilities has, typically, remained rather vague especially when it comes to its practical relevance (Arend and Bromiley, 2009). Our model provides several implications of how organizations might facilitate entrepreneurial initiatives and, thus, support the attainment of dynamic capabilities. For instance, organizations should support actors in sensing the external environment in order to be able to 
assess fit of operative routines with the external environment. Tools that support the integration of external knowledge (e.g., customer feedback forms, market surveys, communities of practice with external participants) might be an example of how this could be accomplished.

Moreover, our model shows that the organizational context is important for the emergence of entrepreneurial initiatives. First, these insights emphasize the need to design organizational contexts that enable individuals to multiply their efforts and nurture entrepreneurial initiatives. For instance, organizations might enable individuals that have particular intentions to change operative routines to connect with others that also support this idea. Second, managers should also create a context in which entrepreneurial initiatives flourish. Research on corporate entrepreneurship provides insights on the properties (e.g., rewards, management support, work discretion) of such an environment (e.g. Kuratko et al., 2014). Change managers might also apply those insights in order to facilitate a context that fosters the emergence of entrepreneurial initiatives and actors who are willing drive organizational change (Will, 2015).

\subsection{Limitations and future research}

Our study has several limitations, which suggest directions for future research. First, our model specifies entrepreneurial initiatives as a specific microfoundation of dynamic capabilities. Our model, therefore, contributes to research that emphasizes the entrepreneurial nature of dynamic capabilities (e.g. Teece, 2012, 2014, 2016). However, our conceptualization of entrepreneurial initiatives remains rather general in nature. Further research should explore the concise characteristics of diverse entrepreneurial initiatives in relation to dynamic capabilities. The following questions arise: How do different types of entrepreneurial initiatives (e.g., issue selling, bootlegging) interact with operative routines? How do those initiatives become collective and how do "ideas" disperse across the organization? When do entrepreneurial initiatives fail? Furthermore, we conceptualize entrepreneurial initiatives as a specific microfoundation of dynamic capabilities. However, there might be further entrepreneurial microfoundations of dynamic capabilities. Examples are structurally decoupled units that act in an entrepreneurial way, compensation and incentive systems as well as entrepreneurial motivations and cognition (Salvato et al., 2009). Future research might unravel and compare those entrepreneurial microfoundations of dynamic capabilities. 
Second, in emphasizing the role of actors below top management, our study remains rather general in nature. Wooldridge et al. (2008), for example, state that middle managers exert agency in a completely different way when compared to top management. Lower level employees might also differ from middle managers in this respect. Future research on the microfoundations of dynamic capabilities should clarify how diverse groups of actors, in terms of profession and hierarchical position, execute entrepreneurial initiatives shaping operative routines. This aspect might be a fruitful avenue for research as different actors participate in different routines (e.g., interdependencies between routines in which they participate) providing diverse contexts that might foster or constrain entrepreneurial initiatives.

Third, research on organizational routines might provide insights into the tension addressed in this paper. Eisenhardt and Sull (2001), for instance, explain that routines might also be semistructured in nature. Those routines serve as frameworks that allow for a diversity of behavior. Thus, a broad spectrum of entrepreneurial behavior exists that seems to be radical in nature from an individual's perspective; however, it is only incremental if we analyze the change in routines. Future research might answer questions that are linked to the structuring of routines: is there a difference in how entrepreneurial initiatives impact structured and semi-structured routines? Is disruption a relevant mechanism in semi-structured routines? Consideration of research that regards routines from a practice perspective might also fertilize this discussion (Feldman and Pentland, 2003; Parmigiani and Howard-Grenville, 2011).

Fourth, our model does not include the notion of time and iteration, opening further opportunities for research: How often does disruption occur? Are infrequent phases of disruption followed by phases of routine stabilization? How do entrepreneurial initiatives evolve over time? Research that applies procedural and temporal perspectives to understand dynamic capabilities might provide interesting insights (Helfat and Peteraf, 2003). This might particularly be interesting since the ontological assumptions of such perspectives (i.e., procedural focus) differ from the assumptions of microfoundations research (i.e., focus on lower level entities and phenomena).

In conclusion, the tension between routinization and entrepreneurship in dynamic capability research is an important issue. Our paper sheds light on this issue by providing a model in which entrepreneurial initiatives represent a microfoundation of dynamic capabilities. However, we believe that this tension deserves further consideration and hope that our paper stimulates research that continues to explore the nature of dynamic capabilities. 


\section{References}

Abell, P., Felin, T. and Foss, N. (2008), "Building micro-foundations for the routines, capabilities, and performance links", Managerial and Decision Economics, Vol. 29 No. 6, pp. 489-502.

Abetti, P.A. (1997), "The birth and growth of Toshiba's laptop and notebook computers: A case study in Japanese corporate venturing", Journal of Business Venturing, Vol. 12 No. 6, pp. 507529.

Acquaah, M. (2007), "Managerial social capital, strategic orientation, and organizational performance in an emerging economy", Strategic Management Journal, Vol. 28 No. 12, pp. 1235-1255.

Adner, R. and Helfat, C.E. (2003), "Corporate effects and dynamic managerial capabilities", Strategic Management Journal, Vol. 24 No. 10, pp. 1011-1025.

Ahuja, G. and Lampert, C.M. (2001), "Entrepreneurship in the large corporation: A longitudinal study of how established firms create breakthrough inventions", Strategic Management Journal, Vol. 22 No. 6-7, pp. 521-543.

Alpkan, L., Bulut, C., Gunday, G., Ulusoy, G. and Kilic, K. (2010), "Organizational support for intrapreneurship and its interaction with human capital to enhance innovative performance", Management Decision, Vol. 48 No. 5, pp. 732-755.

Ambrosini, V., Bowman, C. and Collier, N. (2009), "Dynamic capabilities: An exploration of how firms renew their resource base", British Journal of Management, Vol. 20 No. S1, pp. 9-24.

Amit, R. and Zott, C. (2001), "Value creation in e-business", Strategic Management Journal, Vol. 22 No. 6-7, pp. 493-520.

Antoncic, B. and Hisrich, R.D. (2003), "Clarifying the intrapreneurship concept", Journal of Small Business and Enterprise Development, Vol. 10 No. 1, pp. 7-24.

Aragón-Correa, J.A. and Sharma, S. (2003), "A contingent resource-based view of proactive corporate environmental strategy", Academy of Management Review, Vol. 28 No. 1, pp. 7188.

Arend, R.J. and Bromiley, P. (2009), "Assessing the dynamic capabilities view: Spare change, everyone?", Strategic Organization, Vol. 7 No. 1, pp. 75-90.

Argote, L. (1982), "Input uncertainty and organizational coordination in hospital emergency units", Administrative Science Quarterly, Vol. 27 No. 3, pp. 420-434. 
Arthur, W.B. (1989), "Competing technologies, increasing returns, and lock-in by historical events", The Economic Journal, Vol. 99 No. 394, pp. 116-131.

Ates, N.Y., Ahn, Y. and Wooldridge, B. (2015), "A psychological perspective on middle managers' strategic championing behavior", in Academy of Management Proceedings, Vancouver.

Augsdorfer, P. (2005), "Bootlegging and path dependency", Research Policy, Vol. 34 No. 1, pp. 1-11.

Baker, T. and Pollock, T.G. (2007), "Making the marriage work: The benefits of strategy's takeover of entrepreneurship for strategic organization", Strategic Organization, Vol. 5 No. 3, pp. 297312.

Barney, J.B. and Felin, T. (2013), "What are microfoundations?", Academy of Management Perspectives, Vol. 27 No. 2, pp. 138-155.

Barreto, I. (2010), "Dynamic capabilities: A review of past research and an agenda for the future", Journal of Management, Vol. 36 No. 1, pp. 256-280.

Barringer, B.R. and Bluedorn, A.C. (1999), "The relationship between corporate entrepreneurship and strategic management", Strategic Management Journal, Vol. 20 No. 5, pp. 421-444.

Benner, M.J. and Tushman, M.L. (2003), "Exploitation, exploration, and process management: The productivity dilemma revisited", Academy of Management Review, Vol. 28 No. 2, pp. 238256.

Bourgeois, L.J., III and Eisenhardt, K.M. (1988), "Strategic decision processes in high velocity environments: Four cases in the microcomputer industry", Management Science, Vol. 34 No. 7, pp. 816-835.

Boyett, I. and Currie, G. (2004), "Middle managers moulding international strategy: An Irish startup in Jamaican telecoms", Long Range Planning, Vol. 37 No. 1, pp. 51-66.

Burgelman, R.A. (1983a), "Corporate entrepreneurship and strategic management: Insights from a process study", Management Science, Vol. 29 No. 12, pp. 1349-1364.

Burgelman, R.A. (1983b), "A process model of internal corporate venturing in the diversified major firm", Administrative Science Quarterly, Vol. 28 No. 2, pp. 223-244.

Cohen, M.D., Burkhart, R., Dosi, G., Egidi, M., Marengo, L., Warglien, M. and Winter, S. (1996), "Routines and other recurring action patterns of organizations: Contemporary research issues", Industrial and Corporate Change, Vol. 5 No. 3, pp. 653-698. 
Collinson, S. and Wilson, D.C. (2006), "Inertia in Japanese organizations: Knowledge management routines and failure to innovate", Organization Studies, Vol. 27 No. 9, pp. 13591387.

Collis, D.J. (1994), "Research note: How valuable are organizational capabilities?", Strategic Management Journal, Vol. 15, pp. 143-152.

Courpasson, D., Dany, F. and Martí, I. (2014), "Organizational entrepreneurship as active resistance: A struggle against outsourcing", Entrepreneurship Theory and Practice, Vol. 40 No. 1, pp. 131-160.

Covin, J.G. and Miles, M.P. (1999), "Corporate entrepreneurship and the pursuit of competitive advantage", Entrepreneurship Theory and Practice, Vol. 23 No. 3, pp. 47-63.

Covin, J.G. and Slevin, D.P. (1991), "A conceptual model of entrepreneurship as firm behavior", Entrepreneurship Theory and Practice, Vol. 16 No. 1, pp. 7-24.

Cyert, R.M. and March, J.G. (1963), A Behavioral Theory of the Firm, Prentice-Hall, Englewood Cliffs.

De Jong, J.P.J., Parker, S.K., Wennekers, S. and Wu, C.-H. (2015), "Entrepreneurial behavior in organizations: Does job design matter?", Entrepreneurship Theory and Practice, Vol. 39 No. 4, pp. 981-995.

Di Stefano, G., Peteraf, M.A. and Verona, G. (2014), "The organizational drivetrain: A road to integration of dynamic capabilities research", Academy of Management Perspectives, Vol. 28 No. 4, pp. 307-327.

Dosi, G., Faillo, M. and Marengo, L. (2008), "Organizational capabilities, patterns of knowledge accumulation and governance structures in business firms: An introduction", Organization Studies, Vol. 29 No. 8-9, pp. 1165-1185.

Dosi, G., Nelson, R.R. and Winter, S. (2000), The nature and dynamics of organizational capabilities, Oxford University Press, New York.

Dutta, S., Zbaracki, M.J. and Bergen, M. (2003), "Pricing process as a capability: A resource-based perspective", Strategic Management Journal, Vol. 24 No. 7, pp. 615-630.

Dutton, J.E., Ashford, S.J., O'Neill, R.M. and Lawrence, K.A. (2001), "Moves that matter: Issue selling and organizational change", Academy of Management Journal, Vol. 44 No. 4, pp. 716736. 
Dutton, J.E., Ashford, S.J., O’ Neill, R.M., Hayes, E. and Wierba, E.E. (1997), "Reading the wind: How middle managers assess the context for selling issues to top managers", Strategic Management Journal, Vol. 18 No. 5, pp. 407-423.

Eisenhardt, K.M., Furr, N.R. and Bingham, C.B. (2010), "Crossroads-microfoundations of performance: Balancing efficiency and flexibility in dynamic environments", Organization Science, Vol. 21 No. 6, pp. 1263-1273.

Eisenhardt, K.M. and Martin, J.A. (2000), "Dynamic capabilities: What are they?", Strategic Management Journal, Vol. 21 No. 10-11, pp. 1105-1121.

Eisenhardt, K.M. and Sull, D.N. (2001), "Strategy as simple rules", Harvard Business Review, Vol. 79 No. 1, pp. 105-116.

Engelen, A., Kube, H., Schmidt, S. and Flatten, T.C. (2014), "Entrepreneurial orientation in turbulent environments: The moderating role of absorptive capacity", Research Policy, Vol. 43 No. 8, pp. 1353-1369.

Eriksson, T. (2014), "Processes, antecedents and outcomes of dynamic capabilities", Scandinavian Journal of Management, Vol. 30 No. 1, pp. 65-82.

Ettlie, J.E., Bridges, W.P. and O'Keefe, R.D. (1984), "Organization strategy and structural differences for radical versus incremental innovation", Management Science, Vol. 30 No. 6, pp. 682-695.

Feldman, M.S. and Pentland, B.T. (2003), "Reconceptualizing organizational routines as a source of flexibility and change", Administrative Science Quarterly, Vol. 48 No. 1, pp. 94-118.

Felin, T. and Foss, N.J. (2005), "Strategic organization: A field in search of micro-foundations", Strategic Organization, Vol. 3 No. 4, pp. 441-455.

Felin, T. and Foss, N.J. (2009), "Organizational routines and capabilities: Historical drift and a course-correction toward microfoundations", Scandinavian Journal of Management, Vol. 25 No. 2, pp. 157-167.

Felin, T., Foss, N.J., Heimeriks, K.H. and Madsen, T.L. (2012), "Microfoundations of routines and capabilities: Individuals, processes, and structure", Journal of Management Studies, Vol. 49 No. 8, pp. 1351-1374.

Felin, T., Foss, N.J. and Ployhart, R.E. (2015), "The microfoundations movement in strategy and organization theory", The Academy of Management Annals, Vol. 9 No. 1, pp. 575-632. 
Fulop, L. (1991), "Middle managers: Victims or vanguards of the entrepreneurial movement?", Journal of Management Studies, Vol. 28 No. 1, pp. 25-44.

Gavetti, G. (2005), "Cognition and hierarchy: Rethinking the microfoundations of capabilities' development", Organization Science, Vol. 16 No. 6, pp. 599-617.

Gilbert, C.G. (2005), "Unbundling the structure of inertia: Resource versus routine rigidity", Academy of Management Journal, Vol. 48 No. 5, pp. 741-763.

Glasmeier, A. (1991), "Technological discontinuities and flexible production networks: The case of Switzerland and the world watch industry", Research Policy, Vol. 20 No. 5, pp. 469-485.

Haveman, H.A. (1992), "Between a rock and a hard place: Organizational change and performance under conditions of fundamental environmental transformation", Administrative Science Quarterly, Vol. 37 No. 1, pp. 48-75.

Haynie, J.M., Shepherd, D., Mosakowski, E. and Earley, P.C. (2010), "A situated metacognitive model of the entrepreneurial mindset", Journal of Business Venturing, Vol. 25 No. 2, pp. 217229.

Helfat, C.E., Finkelstein, S., Mitchell, W., Peteraf, M.A., Singh, H., Teece, D.J. and Winter, S.G. (2007), Dynamic Capabilities: Understanding Strategic Change in Organizations, Blackwell Publishing, Malden.

Helfat, C.E. and Martin, J.A. (2015), "Dynamic managerial capabilities: Review and assessment of managerial impact on strategic change", Journal of Management, Vol. 41 No. 5, pp. 12811312.

Helfat, C.E. and Peteraf, M.A. (2003), "The dynamic resource-based view: Capability lifecycles", Strategic Management Journal, Vol. 24 No. 10, pp. 997-1010.

Helfat, C.E. and Peteraf, M.A. (2009), "Understanding dynamic capabilities: Progress along a developmental path", Strategic organization, Vol. 7 No. 1, pp. 91-102.

Helfat, C.E. and Peteraf, M.A. (2015), "Managerial cognitive capabilities and the microfoundations of dynamic capabilities", Strategic Management Journal, Vol. 36, pp. 831850.

Helfat, C.E. and Winter, S.G. (2011), "Untangling dynamic and operational capabilities: Strategy for the (n)ever-changing world", Strategic Management Journal, Vol. 32 No. 11, pp. 12431250. 
Henderson, R.M. and Clark, K.B. (1990), "Architectural innovation: The reconfiguration of existing product technologies and the failure of established firms", Administrative Science Quarterly, Vol. 35 No. 1, pp. 9-30.

Hisrich, R.D. (1990), "Entrepreneurship/intrapreneurship", American Psychologist, Vol. 45 No. 2, pp. 209-222.

Hornsby, J.S., Kuratko, D.F., Holt, D.T. and Wales, W.J. (2013), "Assessing a measurement of organizational preparedness for corporate entrepreneurship", Journal of Product Innovation Management, Vol. 30 No. 5, pp. 937-955.

Hornsby, J.S., Kuratko, D.F., Shepherd, D.A. and Bott, J.P. (2009), "Managers' corporate entrepreneurial actions: Examining perception and position", Journal of Business Venturing, Vol. 24 No. 3, pp. 236-247.

Hornsby, J.S., Kuratko, D.F. and Zahra, S.A. (2002), "Middle managers' perception of the internal environment for corporate entrepreneurship: Assessing a measurement scale", Journal of Business Venturing, Vol. 17 No. 3, pp. 253-273.

Hostager, T.J., Neil, T.C., Decker, R.L. and Lorentz, R.D. (1998), "Seeing environmental opportunities: Effects of intrapreneurial ability, efficacy, motivation and desirability", Journal of Organizational Change Management, Vol. 11 No. 1, pp. 11-25.

Ireland, D.R. and Webb, J.W. (2007), "Strategic entrepreneurship: Creating competitive advantage through streams of innovation", Business Horizons, Vol. 50 No. 1, pp. 49-59.

Ireland, R.D., Covin, J.G. and Kuratko, D.F. (2009), "Conceptualizing corporate entrepreneurship strategy", Entrepreneurship Theory and Practice, Vol. 33 No. 1, pp. 19-46.

Ireland, R.D., Hitt, M.A. and Sirmon, D.G. (2003), "A model of strategic entrepreneurship: The construct and its dimensions", Journal of Management, Vol. 29 No. 6, pp. 963-989.

Jansen, J.J.P., Bosch, F.A.J.V.D. and Volberda, H.W. (2006), "Exploratory innovation, exploitative innovation, and performance: Effects of organizational antecedents and environmental moderators", Management Science, Vol. 52 No. 11, pp. 1661-1674.

Kemper, J., Schilke, O. and Brettel, M. (2013), "Social capital as a microlevel origin of organizational capabilities", Journal of Product Innovation Management, Vol. 30 No. 3, pp. 589-603. 
King, A.A. and Tucci, C.L. (2002), "Incumbent entry into new market niches: The role of experience and managerial choice in the creation of dynamic capabilities", Management Science, Vol. 48 No. 2, pp. 171-186.

Knight, K.E. (1967), "A descriptive model of the intra-firm innovation process", The Journal of Business, Vol. 40 No. 4, pp. 478-496.

Kuratko, D.F. and Audretsch, D.B. (2013), "Clarifying the domains of corporate entrepreneurship", International Entrepreneurship and Management Journal, Vol. 9 No. 3, pp. 323-335.

Kuratko, D.F., Hornsby, J.S. and Covin, J.G. (2014), "Diagnosing a firm's internal environment for corporate entrepreneurship", Business Horizons, Vol. 57 No. 1, pp. 37-47.

Kuratko, D.F., Hornsby, J.S. and Hayton, J. (2015), "Corporate entrepreneurship: The innovative challenge for a new global economic reality", Small Business Economics, Vol. 45 No. 2, pp. 245-253.

Kuratko, D.F., Ireland, R.D., Covin, J.G. and Hornsby, J.S. (2005), "A model of middle-level managers' entrepreneurial behavior", Entrepreneurship Theory and Practice, Vol. 29 No. 6, pp. 699-716.

Kuratko, D.F., Montagno, R.V. and Hornsby, J.S. (1990), "Developing an intrapreneurial assessment instrument for an effective corporate entrepreneurial environment", Strategic Management Journal, Vol. 11 No. 5, pp. 49-58.

Lant, T.K. and Mezias, S.J. (1990), "Managing discontinuous change: A simulation study of organizational learning and entrepreneurship", Strategic Management Journal, Vol. 11, pp. 147-179.

Lassen, A.H., Waehrens, B.V. and Boer, H. (2009), "Re-orienting the corporate entrepreneurial journey: Exploring the role of middle management", Creativity and Innovation Management, Vol. 18 No. 1, pp. 16-23.

Levitt, B. and March, J.G. (1988), "Organizational learning", Annual Review of Sociology, Vol. 14, pp. 319-340.

Lumpkin, G.T. and Dess, G.G. (1996), "Clarifying the entrepreneurial orientation construct and linking it to performance", The Academy of Management Review, Vol. 21 No. 1, pp. 135-172. 
McCarthy, I.P., Lawrence, T.B., Wixted, B. and Gordon, B.R. (2010), "A multidimensional conceptualization of environmental velocity", Academy of Management Review, Vol. 35 No. 4, pp. 604-626.

Miller, D. (1983), "The correlates of entrepreneurship in three types of firms", Management Science, Vol. 29 No. 7, pp. 770-791.

Nadkarni, S. and Narayanan, V.K. (2007), "Strategic schemas, strategic flexibility, and firm performance: The moderating role of industry clockspeed", Strategic Management Journal, Vol. 28 No. 3, pp. 243-270.

Naffziger, D.W., Hornsby, J.S. and Kuratko, D.F. (1994), "A proposed research model of entrepreneurial motivation", Entrepreneurship: Theory and Practice, Vol. 18 No. 3, pp. 2943.

Nelson, R.R. and Winter, S.G. (1982), An Evolutionary Theory of Economic Change, Belknap / Harvard University Press, Cambridge.

Newey, L.R. and Zahra, S.A. (2009), "The evolving firm: How dynamic and operating capabilities interact to enable entrepreneurship", British Journal of Management, Vol. 20 No. s1, pp. S81S100.

Parmigiani, A. and Howard-Grenville, J. (2011), "Routines revisited: Exploring the capabilities and practice perspectives", The Academy of Management Annals, Vol. 5 No. 1, pp. 413-453.

Pavlou, P.A. and El Sawy, O.A. (2011), "Understanding the elusive black box of dynamic capabilities", Decision Sciences, Vol. 41 No. 1, pp. 239-273.

Peng, D.X., Schroeder, R.G. and Shah, R. (2008), "Linking routines to operations capabilities: A new perspective", Journal of Operations Management, Vol. 26 No. 6, pp. 730-748.

Pinchot III, G. (1985), Intrapreneuring: Why You Don't Have to Leave the Corporation to Become an Entrepreneur, Harper \& Row, New York.

Rauch, A., Wiklund, J., Lumpkin, G.T. and Frese, M. (2009), "Entrepreneurial orientation and business performance: An assessment of past research and suggestions for the future", Entrepreneurship Theory and Practice, Vol. 33 No. 3, pp. 761-787.

Ren, C.R. and Guo, C. (2011), "Middle managers' strategic role in the corporate entrepreneurial process: Attention-based effects", Journal of Management, Vol. 37 No. 6, pp. 1586-1610. 
Renzl, B., Rost, M. and Kaschube, J. (2013), "Facilitating ambidexterity with HR practices - a case study of an automotive supplier", International Journal of Automotive Technology and Management, Vol. 13 No. 3, pp. 257-272.

Rothaermel, F.T. and Hess, A.M. (2007), "Building dynamic capabilities: Innovation driven by individual-, firm-, and network-level effects", Organization Science, Vol. 18 No. 6, pp. 898921.

Salvato, C. (2009), "Capabilities unveiled: The role of ordinary activities in the evolution of product development processes", Organization Science, Vol. 20 No. 2, pp. 384-409.

Salvato, C. and Rerup, C. (2011), "Beyond collective entities: Multilevel research on organizational routines and capabilities", Journal of Management, Vol. 37 No. 2, pp. 468-490.

Salvato, C., Sciascia, S. and Alberti, F.G. (2009), "The microfoundations of corporate entrepreneurship as an organizational capability", The International Journal of Entrepreneurship and Innovation, Vol. 10 No. 4, pp. 279-289.

Santos, F.M. and Eisenhardt, K.M. (2005), "Organizational boundaries and theories of organization", Organization Science, Vol. 16 No. 5, pp. 491-508.

Schreyögg, G. and Kliesch-Eberl, M. (2007), "How dynamic can organizational capabilities be? Towards a dual-process model of capability dynamization", Strategic Management Journal, Vol. 28 No. 9, pp. 913-933.

Shane, S. and Venkataraman, S. (2000), "The promise of entrepreneurship as a field of research", Academy of management review, Vol. 25 No. 1, pp. 217-226.

Sharma, P. and Chrisman, J.J. (1999), "Toward a reconciliation of the definitional issues in the field of corporate entrepreneurship", Entrepreneurship Theory and Practice, Vol. 23 No. 3, pp. 11-28.

Stene, E.O. (1940), "An approach to a science of administration", The American Political Science Review, Vol. 34 No. 6, pp. 1124-1137.

Stopford, J.M. and Baden-Fuller, C.W.F. (1994), "Creating corporate entrepreneurship", Strategic Management Journal, Vol. 15 No. 7, pp. 521-536.

Sydow, J., Schreyögg, G. and Koch, J. (2009), "Organizational path dependence: Opening the black box", Academy of Management Review, Vol. 34 No. 4, pp. 689-709. 
Teece, D.J. (2007), "Explicating dynamic capabilities: The nature and microfoundations of (sustainable) enterprise performance", Strategic Management Journal, Vol. 28 No. 13, pp. 1319-1350.

Teece, D.J. (2012), "Dynamic capabilities: Routines versus entrepreneurial action", Journal of Management Studies, Vol. 49 No. 8, pp. 1395-1401.

Teece, D.J. (2014), "The foundations of enterprise performance: Dynamic and ordinary capabilities in an (economic) theory of firms", Academy of Management Perspectives, Vol. 28 No. 4, pp. 328-352.

Teece, D.J. (2016), "Dynamic capabilities and entrepreneurial management in large organizations: Toward a theory of the (entrepreneurial) firm", European Economic Review, Vol. 86, pp. 202216.

Teece, D.J. and Pisano, G. (1994), "The dynamic capabilities of firms: An introduction", Industrial and Corporate Change, Vol. 3 No. 3, pp. 537-556.

Teece, D.J., Pisano, G. and Shuen, A. (1997), "Dynamic capabilities and strategic management", Strategic Management Journal, Vol. 18 No. 7, pp. 509-533.

Vergne, J.-P. and Durand, R. (2011), "The path of most persistence: An evolutionary perspective on path dependence and dynamic capabilities", Organization Studies, Vol. 32 No. 3, pp. 365382.

Wales, W., Monsen, E. and McKelvie, A. (2011), "The organizational pervasiveness of entrepreneurial orientation", Entrepreneurship Theory and Practice, Vol. 35 No. 5, pp. 895923.

Wales, W.J., Parida, V. and Patel, P.C. (2013), "Too much of a good thing? Absorptive capacity, firm performance, and the moderating role of entrepreneurial orientation", Strategic Management Journal, Vol. 34 No. 5, pp. 622-633.

Wenzel, M. (2015), "Path dependence and the stabilization of strategic premises: How the funeral industry buries itself", Business Research, Vol. 8 No. 2, pp. 265-299.

Wilden, R., Devinney, T.M. and Dowling, G.R. (2016), "The architecture of dynamic capability research identifying the building blocks of a configurational approach", Academy of Management Annals, Vol. 10 No. 1, pp. 997-1076. 
Will, M.G. (2015), "Successful organizational change through win-win: How change managers can create mutual benefits", Journal of Accounting \& Organizational Change, Vol. 11 No. 2, pp. 193-214.

Winter, S.G. (2003), "Understanding dynamic capabilities", Strategic Management Journal, Vol. 24 No. 10, pp. 991-995.

Winter, S.G. (2013), "Habit, deliberation, and action: Strengthening the microfoundations of routines and capabilities", The Academy of Management Perspectives, Vol. 27 No. 2, pp. 120137.

Wohlgemuth, V. and Wenzel, M. (2015), "Dynamic capabilities and routinization", Journal of Business Research, Vol. 69 No. 5, pp. 1944-1948.

Wooldridge, B., Schmid, T. and Floyd, S.W. (2008), "The middle management perspective on strategy process: Contributions, synthesis, and future research", Journal of Management, Vol. 34 No. 6, pp. 1190-1221.

Zahra, S.A. (1993), "Environment, corporate entrepreneurship, and financial performance: A taxonomic approach", Journal of Business Venturing, Vol. 8 No. 4, pp. 319-340.

Zahra, S.A., Sapienza, H.J. and Davidsson, P. (2006), "Entrepreneurship and dynamic capabilities: A review, model and research agenda", Journal of Management Studies, Vol. 43 No. 4, pp. 917-955.

Zollo, M. and Winter, S.G. (2002), "Deliberate learning and the evolution of dynamic capabilities", Organization Science, Vol. 13 No. 3, pp. 339-351. 
Figure 1

Entrepreneurial initiatives as a microfoundation of dynamic capabilities

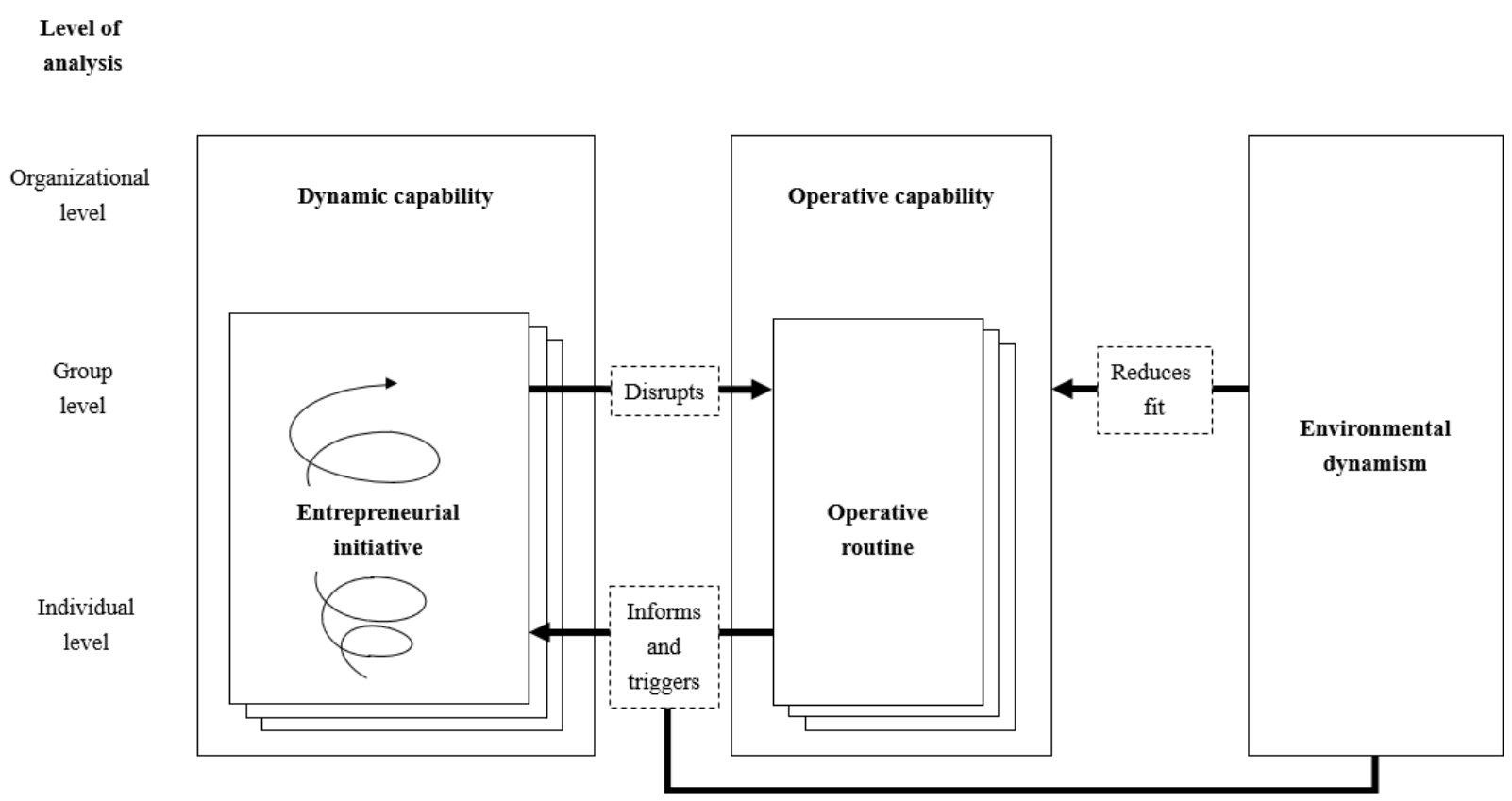

